\title{
MEASURING THE PERFORMANCE OF REGIONAL GOVERNMENT: USING DATA ENVELOPMENT ANALYSIS (DEA) APPROACH
}

\author{
Zainal Putra ${ }^{1 *}$, Muzakir ${ }^{2}$, and Ishak Hasan ${ }^{3}$ \\ ${ }^{1,2}$ Universitas Teuku Umar, Indonesia \\ ${ }^{3}$ Universitas Syiah Kuala, Indonesia
}

\begin{abstract}
The realization of regional government expenditure in Aceh Province from 2011 - 2015 has reached the figure of Rp84.260.616.926.552,00. However, the indicator data of Aceh people's welfare in 2016 provided information of unemployment rate in Aceh in 2015 at 9,93\%. This exceeds the national unemployment rate in the same period of 6.2\%. Likewise, the poverty rate of Aceh Province in 2015 was at 17.08\%. While nationally, the unemployment rate was at $11.13 \%$.

This condition indicated that the regional government were still unable to prosper the people, which also means that the governments were underperformed. This was possible because of inefficient use of resources. Efficiency does not only apply to private sector but also public sector. public sector organizations are now required to be able to operate efficiently to improve the performance. Nowadays, the performance of the local government has been criticized by the public. Therefore, it is necessary to develop a performance measurement toward public organization to know the extent of performance in a certain period accurately. This study aims to determine the efficiency level of regency / city governments in Aceh Province. By using the Data Envelopment Analysis (DEA) approach, it is possible to observe which regency / city governments are performing well. This study uses input variables including regional expenditure, assets, population, civil servants and area. Output variables used include Regional Original Income (PAD), Human Development Index (HDI) and Per capita Income.

The result shows that from 23 regency / city governments in Aceh Province, in the overall average from 2011 - 2015, there were only 5 regency / city governments (21.74\%) who were efficient in running their government (efficiency score 1.00), namely Banda Aceh, Langsa, Lhokseumawe, Sabang and Subulussalam. Therefore, the regency / city government has a good performance.
\end{abstract}

Keywords: Performance and DEA, Regency / city governments

\section{INTRODUCTION}

There are 18 regency government and 5 city government in Aceh. Based on the Republic of Indonesia BPK LHP data on LKPD, total assets of all regency / city governments in Aceh Province until 2015 were amounted to Rp.43,431,771,119,138.60. In addition, the realization of regional expenditure from 2011 - 2015 had reached the figure of Rp. 84,260,616,926,552.00.

Table 1 Realization of Regional Expenditures of Regency / City Governments in Aceh Province, Period 2011 - 2015

\begin{tabular}{cc}
\hline Year & $\begin{array}{c}\text { Regional Expenditure } \\
\text { Realization }\end{array}$ \\
\hline 2015 & $23.195 .489 .404 .293,10$ \\
2014 & $20.119 .142 .615 .243,90$ \\
2013 & $15.362 .169 .716 .206,90$ \\
2012 & $13.165 .429 .386 .639,50$ \\
2011 & $12.418 .385 .804 .168,70$ \\
\hline Total & $\mathbf{8 4 . 2 6 0 . 6 1 6 . 9 2 6 . 5 5 2 , 0 0}$ \\
\hline
\end{tabular}

* Corresponding author. Email address: zainalputra@utu.ac.id 
From the results of the evaluation of the performance accountability report for the 2017 fiscal year submitted by Ministry of Administrative and Bureaucratic Reform (Menpan RB) on January 28, 2018 to the regional government, it was found that the Aceh Provincial Government received "B" grade. Meanwhile, for regency / city government, the average score is "C" (Siswanto: 2018). It should be noted that the performance evaluation of local governments is carried out by the Ministry of Administrative and Bureaucratic Reform. In accordance to Permenpan and RB Number 25 of 2012 concerning the Implementation Guidelines for Evaluating the Performance of Government Agencies, there are 6 (six) categories of performance appraisal accountability of local governments, namely: AA Category, with the scores of $>85$ 100 , satisfactory. A Category, with the score of $>75-85$, very good. B Category, with the score of $>65-75$, good. CC category, with the score of $>50-65$, enough. C Category, with the score of $>30-50$, less. D Category, with the scores of $0-30$, very less.

Therefore, Aceh Provincial Government with "B" grade can be categorized as "performing well". Whereas the regency / city governments that " $\mathrm{C}$ " grade, are categorized as underperformed. Thus, it can be concluded that the funds of $\mathrm{Rp}$. $84,260,616,926,552.00$ which have been spent by the regency / city government in the period 2011 - 2015 have not been able to prosper the community. This also means that the regional / city governments in Aceh Province were not efficient in using the resources which results in not achieving optimal output. Ideally, every budget spent by the local government should provide added value to the community.

This is supported by the indicator data of Aceh people's welfare in 2016 which provided information of unemployment rate in Aceh in 2015 is at $9,93 \%$. This exceeds the national unemployment rate in the same period of $6.2 \%$. Likewise, the poverty rate of Aceh Province in 2015 was at $17.08 \%$. While nationally, the unemployment rate was at $11.13 \%$.

This condition indicated that the local government werestill unable to prosper the people, which also means that the governments were underperformed. This is possible because of inefficient use of resources. Efficiency does not only apply to private sector but also public sector. public sector organizations are now required to be able to operate efficiently to improve the performance. Nowadays, the performance of the local government has been criticized by the public. In other words, there is increasingly high demand of the society for the accountability of the performance of state administrators for the trust mandated to them (Mahsun, 2016: 26). Therefore, it is necessary to develop a performance measurement toward public organization to know the extent of performance in a certain period accurately.

Mardiasmo (2009: 121) states that accountability is not just the ability to show how public money is spent, but includes the ability to show that public money has been spent economically, efficiently and effectively. Therefore the government is obliged to improve the efficiency and effectiveness of public services.

Thus, this study aims to analyse the efficiency level of regency/city government in Aceh province to understand which regency / city governments have good performance.

\section{LITERATURE REVIEW}

\section{Regional Government}

Every regional is led by a head of regional government known as local leader. The local leader of provincial area is called governor, for regency area it is called the regent, and for the city area it is called the mayor. The term of office of the regent/mayor is for 5 (five) years starting from inauguration day and can be re-elected for the same position for only one term of office afterwards. Many people misunderstood the terminology of regional government and local leader. Referring to Article 1 paragraph (2) and paragraph (3) of Law Number 23 Year 2014 concerning Regional Government, what is meant by regional government is the administration of 
government affairs by regional governments and regional legislatures according to the principle of autonomy and co-administration with the principle of autonomy wideranging in the system and principles of the Unitary State of the Republic of Indonesia as referred to in the 1945 Constitution of the Republic of Indonesia. While the local leader is the regional head as an element of regional government administrators who lead the implementation of government affairs under the authority of autonomous regions.

Structurally, the Indonesian government is divided into provincial and regency / city governments. The governor as head of the provincial government is the representative of the central government in the region. In order to assist in the administration of government affairs which are the authority of the regions, the regional heads form the regional apparatus. Local government administrators in carrying out regional governance are guided by the principles of the implementation of state governance which consists of: legal certainty, orderly state administration, public interest, openness, proportionality, professionalism, accountability, efficiency, effectiveness and fairness (Article 58 of Law No. 23/2014 on Government Area).

There are 18 regency governments and 5 city governments in Aceh, namely Aceh Barat Regency, Aceh Barat Daya Regency, Aceh Besar Regency, Aceh Jaya Regency, Aceh Jaya Regency, Aceh Selatan Regency, Aceh Singkil Regency, Aceh Tamiang Regency, Aceh Tengah Regency, Aceh Tenggara Regency, Aceh Timur Regency, Aceh Timur Regency, Aceh Utara Regency, Bener Meriah Regency, Bireun Regency, Gayo Lues Regency, Nagan Raya Regency, Pidie Regency, Pidie Raya Regency, Simeulue Regency, Banda Aceh City, Langsa City, Lhokseumawe City, Sabang City, dan Subulussalam City.

\section{Regional Government Performance}

In running the government organization, the regional government uses public funds called the Regional Budget (APBD). According to article 1 paragraph (9) ministry of home affair regulation Number 13 of 2006 concerning Guidelines for Regional Financial Management, APBD is the annual financial plan of regional government discussed and agreed upon by the regional government and DPRD and stipulated by regional regulations. APBD are implemented from January to December of the year concerned. In addition to routine expenditure on regional equipment, such as employee expenditure and office expenditure, the largest portion of the APBD is used for regional development expenditure and for public service expenditure. The regional government as the party that runs the APBD acts as a reporting entity. The reporting entity is a government unit consisting of one or more accounting entities that are obliged to submit accountability reports in the form of financial statements.

In accordance to the mandate of Article 2 of Government Regulation Number 8 of 2006 concerning Financial Reporting and Performance of Government Agencies, the regional government as a reporting entity is obliged to submit performance reports as a form of accountability for the implementation of the Regional Budget, in addition to the obligation to submit financial statements. The regent/mayor on behalf of the regional government submits the performance report and financial report to the DPRD, the people's representative in the area.

According to article 1 paragraph (2) Government Regulation Number 8 of 2006 concerning Financial Reporting and Performance of Government Agencies, performance is defined as the output / outcome of activities / programs that are intended or have been achieved related to the use of budget with measurable quantity and quality. While the performance report is an overview that explains the performance achievements which are compiled based on the work plan stipulated in the framework of implementing the APBD in a concise and complete manner.

Mahsun (2016 : 25) define performance as a description of the level of achievement of an activity / program / policy in achieving the goals, objectives, vision and mission of the organization stated in the organization strategic plan. The term performance is often used to refer to achievement, or the level of success of an 
individual or group. Mahsun (2016: 25) further explained that performance measurement is a process of evaluating the progress of work towards predetermined goals and objectives.

According to Mardiasmo (2009: 121) the public-sector performance measurement system is a system that aims to help public sector managers to assess the achievement of a strategy through financial and non-financial instruments. Performance measurement systems can be used as a performance control tool. It is known that performance measurement is very important to assess the accountability of organizations and managers in producing better public services. Mardiasmo (2009: 121) further states that accountability is not just the ability to show how public money is spent but includes the ability to show that public money has been spent economically, efficiently and effectively.

Zhonghua and Ye (2012) stated that public sector organizations are unique. generally, this organization have many stakeholders and goals. Furthermore according to Zhonghua and Ye (2012) there are external factors and internal factors that affect the performance of public sector organizations. The external factors are the targeted service market and market share. While internal factors consist of: a. organizational strategy and objectives; b. System; c. structure and type of organization; d. Organizational management level; e. organizational culture; f. high organizational commitment; g. Autonomy for decision making.

Mardiasmo (2009: 122) admits that measuring the performance of public sector organizations is not as easy as measuring the performance of private sector organizations. This is because public sector organizations are multi-dimensional and non-profit oriented. On the other hand, performance measurements are used by the legislature to determine the feasibility of service costs charged to the users of public services.

Nowadays, the performance of government agencies has received much attention from the public. They began to question the benefits obtained from the services of government agencies. In other words, the demands of the community are increasingly high for the accountability of the performance of state administrators for the trust mandated to them (Mahsun, 2016: 26). Therefore, it is necessary to develop a performance measurement toward public organization to know the extent of performance in a certain period accurately compares to what has been planned.

Article 20 paragraph (6) Government Regulation Number 8 of 2006 concerning Financial Reporting and Performance of Government Agencies, confirms that there is a relationship between performance reports and financial statements. It was explained that the relationship lies in the implementation of government activities / programs, which use a number of financial resources. Without budget support, the government activities / programs cannot be implemented. The accountability of the implementation of government activities / programs supported by the budget is explained in the performance report. While the responsibility for using a number of financial resources in the context of implementing government activities / programs is explained in financial statements.

As a form of accountability to the people, the regional head is obliged to submit a performance report to the DPRD no later than 2 (two) months after the fiscal year ends. The performance report contains the output of each activity and the results achieved from each program as stipulated in the APBD implementation document. The performance accountability system of government agencies is developed in an integrated manner with planning systems, budgeting systems, treasury systems and government accounting systems.

The assessment of the financial management title by the regional government is carried out by the Supreme Audit Agency (BPK) through an opinion statement on the local government financial report (LKPD). Opinion is a professional statement as the conclusion of the examiner regarding the level of fairness of the information presented in the financial statements. According to article 16 paragraph (1) of Law Number 15 of 2004 concerning Examination of Management and Responsibility of State Finance, 
there are 4 (four) types of opinions that can be given by the examiner, namely: unqualified opinion, qualified opinion, adversed opinion and disclaimer of opinion.

The assessment of local government performance is carried out by the Ministry of Administrative Reform and Bureaucratic Reform. According to the Ministry of Administrative Reform and Bureaucratic Reform regulation (Permenpan dan RB) Number 25 Year 2012 concerning Implementation Guidelines for Evaluating Performance Accountability of Government Agencies, there are 6 (six) categories of performance accountability assessment as presented in the table below.

Tabel 2 Performance Accountability Assessment Category of Local Government / Government Agency

\begin{tabular}{cccc}
\hline No. & Category & Scores & Interpretation \\
\hline 1. & AA & $>85-100$ & Satisfactory \\
2. & A & $>75-85$ & Very Good \\
3. & B & $>65-75$ & Good \\
4. & CC & $>50-65$ & Enough \\
5. & C & $>30-50$ & Less \\
6. & D & $0-30$ & Very less \\
\hline
\end{tabular}

Sources: Ministry of administrative and Bureaucratic Reforms regulation number 25 year 2012 concerning Implementation Guidelines for Evaluating Performance Accountability of Government Agencies

Therefore, according to the author, the status of the level opinion on the local government financial statements provided by the BPK to the local government should ideally be in line with the category of regional government performance appraisal provided by ministry of administrative and bureaucratic reforms. Although the evidence in the field are contradicting each other. For example, a regional government gets a unqualified opinion (WTP) from the BPK for its LKPD, but ministry of administrative and bureaucratic reforms provides a "CC" scores for the performancse of the local government

As mentioned above, performance measurement in public sector organizations is multi-dimensional, so it is rather difficult to do. The measurement of performance carried out so far is only based on the achievement of output as previously set. But according to the author it is not enough. The end result of performance measurement in public sector organizations should be the welfare or prosperity felt by the people. Regarding this, as far as the authors know, there has been no research in that direction. Therefore, the author in this study tried to measure the performance of public sector organizations, in this case the regional government in Aceh Province, in a different way by using the Data Envelopment Analysis (DEA) approach. This approach uses multi variable input and multi variable output. Input variables include regional expenditure, assets, population, civil servants and area. Input variables are input resources owned by the organization which further be used to create output.

The output variables used are Regional Original Income (PAD), Human Development Index (HDI) and Per capita Income. PAD is regional income that is gained by the region itself from potential local sources of income, such as regional taxes, regional retribution, the results of separated regional wealth management and other legitimate local revenue. The greater the amount of PAD gained, the more independence an area is. This means that the area is not too dependent on external funding sources. Therefore, the area with higher PAD is performing well.

HDI is an important indicator to measure success in an effort to build the quality of human life. The HDI also explains how the people can access the development result in order to achieve income, health, education and so on. HDI was first introduced by UNDP in 1990. HDI was formed by three basic dimensions, namely longevity and healthy life, knowledge and decent living standards (Central Statistics Agency, 2015). The benefits of HDI include: (a). An important indicator to measure 
success in an effort to build the quality of human life, (b). Can determine the ranking or level of development of a region / country, and (c). As a measure of government performance. Therefore, it is implied that high HDI rate indicates that the area is performing well.

Per capita income is the average income of the population of a country for a certain period. Usually the higher the income per capita rate, the prosperity of the people is considered to be higher. per capita income is calculated by dividing national income (usually gross domestic product) by the number of population in a certain country. Rahardja and Manurung (2004: 221) states that there is a positive relationship between per capita income and the level of social welfare. This means that the higher the income per capita, the higher the level of social welfare. So that people's purchasing power, employment opportunities and the future of the economy are improving.

\section{Data Envelopment Analysis (DEA)}

DEA was first introduced by Charnes, Cooper and Rhodes (1978) from The University of Texas, USA, Harvard University, USA, and State University of New York, USA respectively. Charnes, Cooper and Rhodes (1978) developed DEA to evaluate non-profit sector organizations and public-sector organizations. DEA is then growing and is widely used to measure performance in various other organizations. Linear programming is the underlying methodology that makes the DEA very strong when compared to alternative productivity management tools. DEA has been widely studied, used and analyzed by academics who understand linear programming

According to Yannick, Hongzhong and Thierry (2016), DEA is part of a nonparametric approach and is very useful for measuring the efficiency of decision-making units. In line with that, Firdaus and Hosen (2013) stated that DEA is a non-parametric method used to measure the level of efficiency of an Economic Activity Unit (UKE). In addition, DEA is a method used to evaluate the efficiency of a decision-making unit that is responsible for using a number of inputs to obtain a targeted output. In particular, DEA is the development of linear programming techniques in which there are objective functions and constraint functions.

DEA was developed to measure organizational performance. This technique has been used successfully to assess the performance of a number of organizations that use a variety of similar inputs and also produce a variety of similar outputs. DecisionMaking Units (DMUs) are decision-making units whose efficiency is being measured. Therefore, DEA measures how efficiently a DMU uses available resources to produce a set of outputs (Ramanathan, 2003: 26).

DMU can include manufacturing units, large organizations such as universities, schools, bank branches, hospitals, police stations, tax offices and so on. The performance of DMU assessed in DEA is to use the concept of efficiency or productivity, which is the ratio of total output to total input. The best performing DMUs are given a one or 100 percent efficiency score.DEA is very suitable to measure the level of efficiency (performance) of a non-profit organization or public sector DMU. Whereas with other methods it is difficult to do, because it uses multiple input variables and multiple output variables.

The measurement of local government performance with the DEA approach has never been conducted before. Therefore, the author is only based on the idea of measuring performance on other public sectors that use this DEA approach. The measurement of public sector performance with the DEA approach has been carried out a lot. Hookana (2011) measured the effectiveness, efficiency and quality of public sector services in Finland. Zhonghua and Ye (2012), measured the performance of the public sector in Beijing. Mikusova (2015), measured the efficiency of public universities in Czechoslovakia. Mbonigaba and Oumar (2016), measured the efficiency of City Governments in South Africa in providing health services to the community. Alabdulmenem (2017), measured the efficiency of state universities in Saudi Arabia. Silvia, Alexandrina, Andreea and Razvan (2017), measured performance through the efficiency of the public health service system in Romania. 
MEASURING THE PERFORMANCE OF REGIONAL GOVERNMENT:

USING DATA ENVELOPMENT ANALYSIS (DEA) APPROACH

\section{RESEARCH METHOD}

\section{Research Object}

In this study, data collection was conducted on 23 regency/city governments in Aceh province, $2011-2015$ period or for 5 years.

Table 3 Lists of Regency / City Governments in Aceh Province

\begin{tabular}{llccccc}
\hline \multirow{2}{*}{ No. } & \multirow{2}{*}{ Regency/City } & \multicolumn{5}{c}{ Period } \\
\cline { 2 - 6 } & $\mathbf{2 0 1 1}$ & $\mathbf{2 0 1 2}$ & $\mathbf{2 0 1 3}$ & $\mathbf{2 0 1 4}$ & $\mathbf{2 0 1 5}$ \\
\hline 1. & Aceh Barat & $\sqrt{ }$ & $\sqrt{ }$ & $\sqrt{ }$ & $\sqrt{ }$ & $\sqrt{ }$ \\
2. & Aceh Barat Daya & $\sqrt{ }$ & $\sqrt{ }$ & $\sqrt{ }$ & $\sqrt{ }$ & $\sqrt{ }$ \\
3. & Aceh Besar & $\sqrt{ }$ & $\sqrt{ }$ & $\sqrt{ }$ & $\sqrt{ }$ & $\sqrt{ }$ \\
4. & Aceh Jaya & $\sqrt{ }$ & $\sqrt{ }$ & $\sqrt{ }$ & $\sqrt{ }$ & $\sqrt{ }$ \\
5. & Aceh Selatan & $\sqrt{ }$ & $\sqrt{ }$ & $\sqrt{ }$ & $\sqrt{ }$ & $\sqrt{ }$ \\
6. & Aceh Singkil & $\sqrt{ }$ & $\sqrt{ }$ & $\sqrt{ }$ & $\sqrt{ }$ & $\sqrt{ }$ \\
7. & Aceh Tamiang & $\sqrt{ }$ & $\sqrt{ }$ & $\sqrt{ }$ & $\sqrt{ }$ & $\sqrt{ }$ \\
8. & Aceh Tengah & $\sqrt{ }$ & $\sqrt{ }$ & $\sqrt{ }$ & $\sqrt{ }$ & $\sqrt{ }$ \\
9. & Aceh Tenggara & $\sqrt{ }$ & $\sqrt{ }$ & $\sqrt{ }$ & $\sqrt{ }$ & $\sqrt{ }$ \\
10. & Aceh Timur & $\sqrt{ }$ & $\sqrt{ }$ & $\sqrt{ }$ & $\sqrt{ }$ & $\sqrt{ }$ \\
11. & Aceh Utara & $\sqrt{ }$ & $\sqrt{ }$ & $\sqrt{ }$ & $\sqrt{ }$ & $\sqrt{ }$ \\
12. & Bener Meriah & $\sqrt{ }$ & $\sqrt{ }$ & $\sqrt{ }$ & $\sqrt{ }$ & $\sqrt{ }$ \\
13. & Bireuen & $\sqrt{ }$ & $\sqrt{ }$ & $\sqrt{ }$ & $\sqrt{ }$ & $\sqrt{ }$ \\
14. & Gayo Lues & $\sqrt{ }$ & $\sqrt{ }$ & $\sqrt{ }$ & $\sqrt{ }$ & $\sqrt{ }$ \\
15. & Nagan Raya & $\sqrt{ }$ & $\sqrt{ }$ & $\sqrt{ }$ & $\sqrt{ }$ & $\sqrt{ }$ \\
16. & Pidie & $\sqrt{ }$ & $\sqrt{ }$ & $\sqrt{ }$ & $\sqrt{ }$ & $\sqrt{ }$ \\
17. & Pidie Jaya & $\sqrt{ }$ & $\sqrt{ }$ & $\sqrt{ }$ & $\sqrt{ }$ & $\sqrt{ }$ \\
18. & Simeulue & $\sqrt{ }$ & $\sqrt{ }$ & $\sqrt{ }$ & $\sqrt{ }$ & $\sqrt{ }$ \\
19. & Banda Aceh & $\sqrt{ }$ & $\sqrt{ }$ & $\sqrt{ }$ & $\sqrt{ }$ & $\sqrt{ }$ \\
20. & Langsa & $\sqrt{ }$ & $\sqrt{ }$ & $\sqrt{ }$ & $\sqrt{ }$ & $\sqrt{ }$ \\
21. & Lhokseumawe & $\sqrt{ }$ & $\sqrt{ }$ & $\sqrt{ }$ & $\sqrt{ }$ & $\sqrt{ }$ \\
22. & Sabang & $\sqrt{ }$ & $\sqrt{ }$ & $\sqrt{ }$ & $\sqrt{ }$ & $\sqrt{ }$ \\
23. & Subulussalam & $\sqrt{ }$ & $\sqrt{ }$ & $\sqrt{ }$ & $\sqrt{ }$ & $\sqrt{ }$ \\
\hline
\end{tabular}

\section{Research Variable and Data Collection.}

This study uses 5 input variables and 3 output variables. The input variables used are regional expenditure, assets, population, civil servants and area. While the output variables used are regional income (PAD), human development index, and income per capita.

The data for input and output variables were obtained from Regency / City documents issued by the Central Bureau of Statistics (BPS) regency / city from 2011 2015 in the form of figures. Some data were obtained from audited financial report document issued by the Supreme Audit Agency (BPK) Representatives of Aceh Province for each regency / city in Aceh Province from 2011 - 2015. 
Table 4 Operational Variables

\begin{tabular}{|c|c|c|c|}
\hline Variables & Definition & & Scale \\
\hline \multicolumn{4}{|l|}{ A. Input Variables } \\
\hline 1.Regional Expenditure & $\begin{array}{l}\text { Regional expenditure is the regional } \\
\text { government's obligation which is } \\
\text { recognized as a deduction from net worth. } \\
\text { Regional expenditure is measured in Rupiah. } \\
\text { Data on regional expenditures are obtained } \\
\text { from the report of BPK audit result of Aceh } \\
\text { province on the Local Government Financial } \\
\text { Statements (LKPD) in Aceh Province. }\end{array}$ & {$[1] \&[2]$} & Ratio \\
\hline 2. Asset & $\begin{array}{l}\text { Assets are economic resources controlled } \\
\text { and / or owned by the government as a result } \\
\text { of past events and from which future } \\
\text { economic and / or social benefits are } \\
\text { expected to be obtained, both by the } \\
\text { government and the community, and can be } \\
\text { measured in money unit,including non- } \\
\text { financial resources needed to provide } \\
\text { services to the public and resources } \\
\text { maintained for historical and cultural } \\
\text { reasons. Assets are measured in units of } \\
\text { rupiah. Asset data is obtained from Audit } \\
\text { Report of BPK Representatives of Aceh } \\
\text { Province on Local Government Financial } \\
\text { Statements (LKPD) in Aceh Province. }\end{array}$ & [3] \& [4] & Ratio \\
\hline
\end{tabular}

3. Population Population are all people domiciled in the

[5] \& [6] Ratio territorial area of the regency / city government for 6 months or more and / or those who domicile less than 6 months but aim to settle. Population is measured by person. Population data were obtained from BPS Regency / City in Aceh Province.

4. Civil Servant Civil Servants (PNS) are Indonesian citizens who fulfill certain conditions, are appointed [7] \& [8] Ratio as State Civil Service Officer (ASN) permanently by staffing officials to hold government positions. Civil Servants are measured in person unit. PNS data were obtained from BPS Regency / City in Aceh Province.

\begin{tabular}{ll}
\hline 5. Area & The area is places located in the territorial [9]\& [10] Ratio \\
power of a region (regency / city), both land \\
and sea, in which the jurisdiction of the \\
region (regency / city) is applied. The area \\
ends at the boundary of the region with \\
physical conditions such as rivers, \\
mountains and others. The area is measured \\
in units of m2. Area area data were obtained \\
from BPS Regency / City in Aceh Province.
\end{tabular}

\section{B. Output Variables}

The area is places located in the territorial region (regency / city) is applied. The area ends at the boundary of the region with physical conditions such as rivers, from BPS Regency / City in Aceh Province.

\begin{tabular}{llll}
\hline $\begin{array}{l}\text { 1. Regional Original } \\
\text { Income (PAD) }\end{array}$ & $\begin{array}{l}\text { Regional Original Income (PAD) is all } \\
\text { income received through a regional general } \\
\text { cash account that adds funds equity, is a }\end{array}$ & Ratio \\
\hline
\end{tabular}




\title{
MEASURING THE PERFORMANCE OF REGIONAL GOVERNMENT: USING DATA ENVELOPMENT ANALYSIS (DEA) APPROACH
}

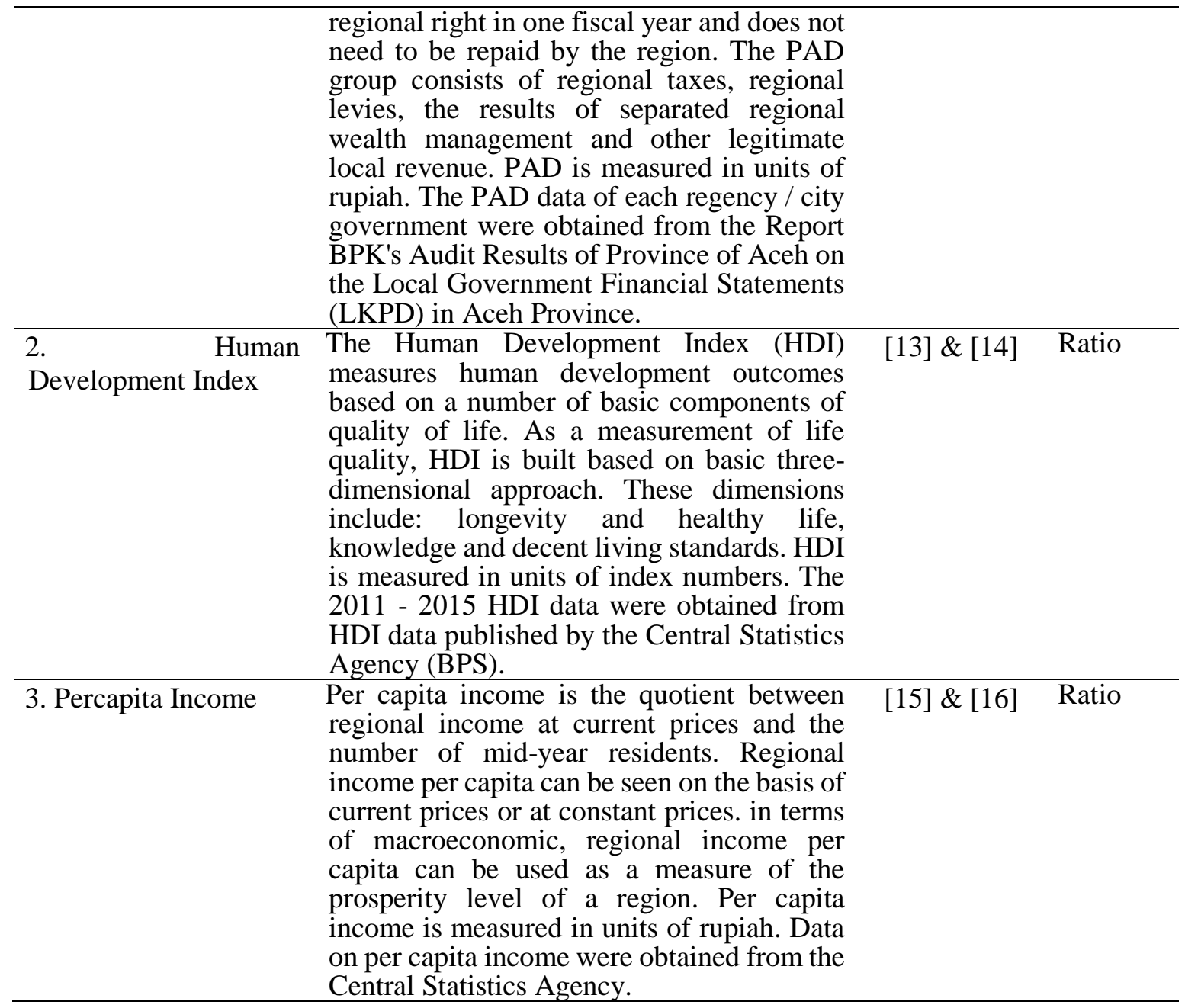

\begin{abstract}
Notes: [1] Law Number 17 year 2003 concerning State Finance. [2], [4], [12] Report on Audit Results of BPK Representatives of Aceh Province on the Local Government Financial Statements (LKPD) in Aceh Province TA 2011, TA 2012, TA 2013, TA 2014 dan TA 2015. [3] Government Regulation Number 71 year 2010 concerning Government Accounting Standards. [5] Aceh Barat Regency in Figures 2018. [6] [8] [10] [16] BPS data, Regency /City in Aceh Province in Figures 2011 - 2015. [7] Law Number 5 Year 2014 concerning State Civil ApparatusLaw Number 17 of 2003 concerning State Finance. [9] https://brainly.co.id/tugas/2078089. [11] Minister of Home Affairs Regulation Number 13 year 2006 concerning Guidelines for Regional Financial Management. [13] Aceh Province Human Development Index Data Year 2011 - 2015, BPS. [15] Gross Domestic Regional Product of Aceh Barat Regency 2005 - 2008, BPS.
\end{abstract}

\section{Data Analysis}

Data analysis in this study uses Data Envelopment Analysis (DEA) approach by using Excel Solver Parameter. DEA is a linear program software which compares several service units of the same form, such as bank, hospital, restaurants, and school based on input and output. The results of the model solutions provide an indication of whether a particular unit is less productive or inefficient, compared to other units (Taylor III, 2013 : 142).

\section{RESULT AND DISCUSSION}

The regency/city government is considered to have good performance if the government are able to carry out the operational efficiently. The more efficient the government in carrying out the operational, the better the performance of the government. This means that the government are able to manage the resources (input) 
better to create maximum output. Regency/city government is efficient if the government are able to achieve efficiency scores of 1,00 .

Based on table 6, it shows that from 23 regencies / cities in Aceh Province, in 2011, there are only 8 regency / city governments (34.78\%) which had good performance by obtaining a perfect efficiency score of 1.00. Those regency / city governments are Aceh Besar, Nagan Raya, Pidie Jaya, Banda Aceh, Langsa, Lhokseumawe, Sabang, Subulussalam. In 2012, there are also 8 regencies/cities $(34,78 \%)$ which had good performance by obtaining a perfect efficiency score of 1,00, namely Aceh Barat daya, Aceh Besar, Pidie Jaya, Banda Aceh, Langsa, Lhokseumawe, Sabang and Subulussalam. in 2013, the number of regencies/cities which had good performance increased to 10 regencies/cities, namely Aceh Tengah, Bener Meriah, Bireuen, Gayo Lues, Pidie Jaya, Banda Aceh, Langsa, Lhokseumawe, Sabang and Subulussalam. In 2014 the best performance decrease to 7 regency / city governments (30.43\%), namely Aceh Tamiang, Nagan Raya, Banda Aceh, Langsa, Lhokseumawe, Sabang and Subulussalam. Finally, in 2015 only 7 regency / city governments (30.43\%) had an efficiency score of 1.00, namely Aceh Tengah, Nagan Raya, Banda Aceh, Langsa, Lhokseumawe, Sabang and Subulussalam.

Table 5 Descriptive Statistics of Input and Output Variables Used in Analysis, Period $2011-2015$

\begin{tabular}{|c|c|c|c|c|}
\hline Variabel & Mean & Standard Deviation & Maksimum & Minimum \\
\hline \multicolumn{5}{|l|}{ Input } \\
\hline Regional Expenditures & $732.701 .016 .752,63$ & $308.680 .088 .176,92$ & $1.716 .336 .104 .583,82$ & $292.902 .595 .170,39$ \\
\hline Asset & $1.791 .114 .426 .683,26$ & $993.767 .232 .986,13$ & $5.212 .093 .165 .869,66$ & $420.306 .944 .761,08$ \\
\hline Population & $209.202,90$ & $132.920,67$ & $583.890,00$ & $31.314,00$ \\
\hline Civil Servant & $5.378,51$ & $2.509,85$ & $11.641,00$ & $1.651,00$ \\
\hline Area & $2.551,44$ & $1.657,56$ & $6.040,60$ & 61,36 \\
\hline \multicolumn{5}{|l|}{ Output } \\
\hline Regional Original Income & $55.535 .335 .601,76$ & 49.159.698.535,99 & $210.501 .782 .065,16$ & $6.099 .446 .461,29$ \\
\hline $\begin{array}{l}\text { Human Development } \\
\text { Index }\end{array}$ & 67,39 & 4,86 & 83,25 & 59,34 \\
\hline Per Capita Income & $17.982 .362,49$ & $9.827 .790,84$ & $53.339 .694,25$ & $3.717 .891,16$ \\
\hline
\end{tabular}

Table 6 Performance of Regency / City Governments in Aceh Province Period 2011 2015

\begin{tabular}{clccccccc}
\hline \multirow{2}{*}{ No. } & \multirow{2}{*}{ Regency/City } & \multicolumn{9}{c}{ Efficiency Scores } & \multirow{2}{*}{ Mean } & Rank \\
\cline { 3 - 6 } & & $\mathbf{2 0 1 1}$ & $\mathbf{2 0 1 2}$ & $\mathbf{2 0 1 3}$ & $\mathbf{2 0 1 4}$ & $\mathbf{2 0 1 5}$ & & \\
\hline 1. & Aceh Barat & 0,80 & 0,72 & 0,70 & 0,82 & 0,84 & 0,78 & 11 \\
2. & Aceh Barat Daya & 0,88 & 1,00 & 0,86 & 0,81 & 0,73 & 0,86 & 7 \\
3. & Aceh Besar & 1,00 & 1,00 & 0,76 & 0,62 & 0,70 & 0,82 & 9 \\
4. & Aceh Jaya & 0,93 & 0,96 & 0,92 & 0,84 & 0,74 & 0,88 & 6 \\
5. & Aceh Selatan & 0,66 & 0,82 & 0,72 & 0,60 & 0,71 & 0,70 & 13 \\
6. & Aceh Singkil & 0,85 & 0,96 & 0,87 & 0,81 & 0,79 & 0,85 & 8 \\
7. & Aceh Tamiang & 0,73 & 0,86 & 0,74 & 1,00 & 0,73 & 0,81 & 10 \\
8. & Aceh Tengah & 0,70 & 0,96 & 1,00 & 0,93 & 1,00 & 0,92 & 4 \\
9. & Aceh Tenggara & 0,60 & 0,73 & 0,72 & 0,62 & 0,55 & 0,64 & 14 \\
10. & Aceh Timur & 0,48 & 0,54 & 0,62 & 0,48 & 0,52 & 0,53 & 16 \\
11. & Aceh Utara & 0,41 & 0,50 & 0,57 & 0,68 & 0,70 & 0,57 & 15 \\
12. & Bener Meriah & 0,89 & 0,82 & 1,00 & 0,83 & 0,88 & 0,88 & 6 \\
13. & Bireuen & 0,56 & 0,56 & 1,00 & 0,85 & 0,85 & 0,76 & 12 \\
\hline
\end{tabular}




\begin{tabular}{|c|c|c|c|c|c|c|c|c|}
\hline 14. & Gayo Lues & 0,87 & 0,97 & 1,00 & 0,78 & 0,65 & 0,85 & 8 \\
\hline 15. & Nagan Raya & 1,00 & 0,91 & 0,85 & 1,00 & 1,00 & 0,95 & 2 \\
\hline 16. & Pidie & 0,55 & 0,80 & 0,87 & 0,85 & 0,97 & 0,81 & 10 \\
\hline 17. & Pidie Jaya & 1,00 & 1,00 & 1,00 & 0,87 & 0,79 & 0,93 & 3 \\
\hline 18. & Simeulue & 0,96 & 0,86 & 0,99 & 0,83 & 0,82 & 0,89 & 5 \\
\hline 19. & Banda Aceh & 1,00 & 1,00 & 1,00 & 1,00 & 1,00 & 1,00 & 1 \\
\hline 20. & Langsa & 1,00 & 1,00 & 1,00 & 1,00 & 1,00 & 1,00 & 1 \\
\hline 21. & Lhokseumawe & 1,00 & 1,00 & 1,00 & 1,00 & 1,00 & 1,00 & 1 \\
\hline 22. & Sabang & 1,00 & 1,00 & 1,00 & 1,00 & 1,00 & 1,00 & 1 \\
\hline 23. & Subulussalam & 1,00 & 1,00 & 1,00 & 1,00 & 1,00 & 1,00 & 1 \\
\hline
\end{tabular}

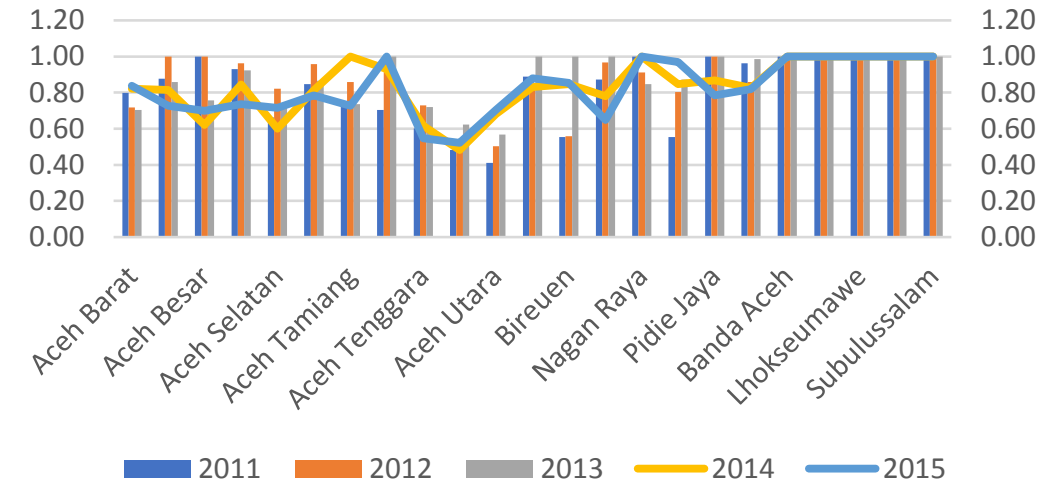

Graph 1 Performance of Regency / City Governments in Aceh Province, Period 2011- 2015

However, based on the average efficiency score, from 2011 - 2015 there are only 5 regencies / city governments $(21.74 \%)$ that had efficiency score of 1.00 , namely Banda Aceh, Langsa, Lhokseumawe, Sabang and Subulussalam. Those regional governments consistently achieved perfect efficiency score of 1,00 every year.

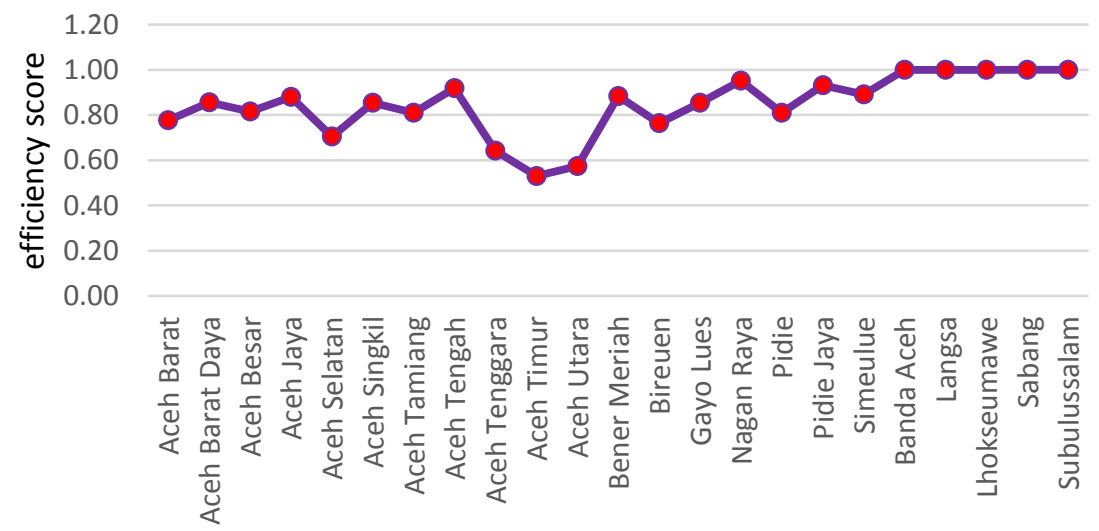

Graph 2 Average Efficiency Score of Regency / City Governments in Aceh Province, Period $2011-2015$

\section{CONCLUSION}

The result of this study shows that of the 23 regency / city governments in Aceh Province, from the overall average from 2011-2015, there were only 5 regency/city governments $(21,74 \%)$ who were efficient in running their government wheels (efficiency score 1.00), namely Banda Aceh, Langsa, Lhokseumawe, Sabang and Subulussalam. Therefore, it can be concluded that these regional government have 
good performance. This is in line with the Unqualified Opinion (WTP) given by the Supreme Audit Agency (BPK) to the 5 regency / city governments from 2008 to 2015 (BPK Representative of Aceh Province, 2016). On the other hand, most regency / city governments in Aceh Province (78.26\%) are inefficient in conducting the government operational and therefore are not considered to have good performance. This is due to excessive use of resources (inputs), while the resulting output is not optimal.

\section{References}

Alabdulmenem, F.H. (2017). Measuring the Efficiency of Public Universities: Using Data Envelopment Analysis (DEA) to Examine Public Universities in Saudi Arabia. International Education Studies, 10 (1), 137 - 143

Anonim. (2018). Pengertian Luas Wilayah. Diakses tanggal 28 Oktober 2018, dari https://brainly.co.id/tugas/2078089.

BPK Perwakilan Provinsi Aceh (2016). Monitoring Opini LKPD Tahun Anggaran 2007 - 2015. Banda Aceh: BPK Perwakilan Provinsi Aceh.

BPK Perwakilan Provinsi Aceh (2018). Laporan Hasil Pemeriksaan atas Laporan Keuangan Pemerintah Daerah (LKPD) di Provinsi Aceh TA 2011 - 2015. Banda Aceh: BPK Perwakilan Provinsi Aceh.

Badan Pusat Statistik (2015). Indeks Pembangunan Manusia 2014. Jakarta: Badan Pusat Statistik.

Badan Pusat Statistik Provinsi Aceh (2017). Indikator Kesejahteraan Rakyat Provinsi Aceh 2016. Banda Aceh: Badan Pusat Statistik Provinsi Aceh.

Badan Pusat Statistik Kabupaten Aceh Barat (2019). Produk Domestik Regional Bruto Kabupaten Aceh Barat 2005 - 2008. Aceh Barat: BPS Kabupaten Aceh Barat.

Badan Pusat Statistik (2016). Data Indeks Pembangunan Manusia Provinsi Aceh Tahun 2011 - 2015. Diakses tanggal 10 Desember 2016, dari ipm.bps.go.id/data/provinsi/metode/baru/1100.

Badan Pusat Statistik Kabupaten / Kota di Provinsi Aceh (2018). Kabupaten / Kota di Provinsi Aceh Dalam Angka 2011 - 2015. Kabupaten/Kota di Provinsi Aceh: Badan Pusat Statistik Kabupaten / Kota di Provinsi Aceh.

Charnes, C., \& Rhodes (1978). Measuring the Efficiency of Decision Making Units. European Journal of Operational Research, (2), 429-444

Firdaus, M.F., \& Hosen, M.N. (2013). Efisiensi Bank Umum Syariah Menggunakan Pendekatan, Two-stage Data Envelopment Analysis. Buletin Ekonomi Moneter dan Perbankan, Oktober 2013. Hal. 167 - 188.

Hookana, H. (2011). Measurement of Effectiveness, Efficiency and Quality in Public Sector Services. Proceedings of the 12th Management International Conference. 23-26 November 2011, Portoroz, Slovenia. Hal. 491 - 510.

Mahsun, M. (2016). Pengukuran Kinerja Sektor Publik. Yogyakarta: BPFEYogyakarta.

Mardiasmo. (2009). Akuntansi Sektor Publik. Yogyakarta: Penerbit Andi Yogyakarta. 
MEASURING THE PERFORMANCE OF REGIONAL GOVERNMENT:

USING DATA ENVELOPMENT ANALYSIS (DEA) APPROACH

Mbonigaba, J., \& Oumar, S.B. (2016). The relative efficiency of South African municipalities in providing public health care. African Journal of Economic and Management Studies, 7 (3), 346-365.

Mikusova, P. (2015). An Aplication of DEA Methodology in Efficiency Measurement ot the Czech Public Universities. Procedia Economics and Finance, (25), Hal. $569-578$.

Peraturan Pemerintah Nomor 8 Tahun 2006 tentang Pelaporan Keuangan dan Kinerja Instansi Pemerintah.

Peraturan Pemerintah Nomor 71 Tahun 2010 tentang Standar Akuntansi Pemerintahan.

Peraturan Menteri Dalam Negeri Nomor 13 Tahun 2006 tentang Pedoman Pengelolaan Keuangan Daerah.

Peraturan Menteri Pendayagunaan Aparatur Negara dan Reformasi Birokrasi Nomor 25 Tahun 2012 tentang Petunjuk Pelaksanaan Evaluasi Akuntabilitas Kinerja Instansi Pemerintah.

Rahardja, P., \& Manurung, M. (2004). Pengantar Ilmu Ekonomi. Jakarta: Fakultas Ekonomi Universitas Indonesia.

Ramanathan, R. (2003). An Introduction to Data Envelopment Analysis, A Tool for Performance Measurement. New Delhi: Sage Publication. ISBN: 81-7829260-2.

Silvia, C., Alexandrina C., Andreea, M., \& Razvan, A. (2017). Performance Through Efficiency in the Public Healthcare System - A DEA Approach in an Emergent Country. Studia Universitatis Babes-Bolyai Oeconomica, 62 (1), $31-49$.

Siswanto, A. (2018). Ini Hasil Evaluasi Kinerja Pemda di Sumatera, Banten dan Jabar. Diakses tanggal 28 Oktober 2018, dari https://finance.detik.com/beritaekonomi-bisnis/d-3833596/ini-hasil-evaluasi-kinerja-pemda-di-sumaterabanten-dan-jabar.

Taylor III, B. W. (2013). Introduction To Management Science. (S. Yagan, Ed.) (11th ed.). New York: PEARSON.

Undang - Undang Nomor 17 Tahun 2003 tentang Keuangan Negara.

Undang-Undang Nomor 15 Tahun 2004 tentang Pemeriksaan Pengelolaan dan Tanggung Jawab Keuangan Negara.

Undang-Undang Nomor 5 Tahun 2014 tentang Aparatur Sipil Negara.

Undang-Undang Nomor 23 Tahun 2014 tentang Pemerintahan Daerah.

Yannick, G.Z.S., Hongzhong, Z. and Thierry, B. (2016). Technical efficiency assessment using data envelopment analysis: an application to the banking sector of Côte d'Ivoire. Procedia - Social and Behavioral Sciences, (235, 198-207.

Zhonghua, C., \& Ye, W. (2012). Research Frontiers in Public Sector Performance Measurement. Physics Procedia, (25), 793 - 799. 